\title{
INTERNATIONAL ONLINE CONFERENCE \\ "THE MONGOLS IN CENTRAL EUROPE: \\ THE PROFILE AND IMPACT OF THEIR THIRTEENTH-CENTURY \\ INVASIONS" (BUDAPEST, NOVEMBER 26-27, 2020)
}

\author{
Aleksandar Uzelac \\ Institute of History, Belgrade \\ Belgrade, Serbia \\ aleksandar.uzelac@iib.ac.rs
}

\begin{abstract}
On November 26 and 27, 2020, an international online conference, "The Mongols in Central Europe: The Profile and Impact of Their thirteenth-century Invasions", took place in Budapest. The conference was organized within the framework of the Project "The Mongol Invasion of Hungary in Its Eurasian Context", led by Balázs Nagy. The conference gathered approximately twenty participants from ten countries. Its proceedings will be published in 2021. This volume is expected to be a useful addition to the existing literature in the field of the relations between of the Mongol Empire and Medieval Europe, especially with consideration toward the importance of the closer mutual collaboration between historians and archaeologists from various countries of Central and Southeast Europe. This was emphasized as one of the primary goals of the event.
\end{abstract}

Keywords: online conference, Mongol invasion of Europe, Medieval Hungary, Central Europe historical sources, archaeology

For citation: Uzelac A. International Online Conference "The Mongols in Central Europe: The Profile and Impact of Their thirteenth-century Invasions" (Budapest, November 26-27, 2020). Zolotoordynskoe obozrenie=Golden Horde Review. 2021, vol. 9, no. 1, pp. 224-226. DOI: 10.22378/2313-6197.2021-9-1.224-226

The conference titled "The Mongols in Central Europe: The Profile and Impact of Their thirteenth-century Invasions" was planned to be held in late March 2020 in Budapest, but it had to be postponed due to the COVID-19 pandemics. However, thanks to the efforts of the organizers, gathered around the project "The Mongol Invasion of Hungary in Its Eurasian Context" (A tatárjárás Magyarországon és a mongol hódítás eurázsiai összefüggései) and led by Balázs Nagy (Eötvös Loránd University, Budapest), it was rescheduled as an online event, hosted in Budapest on November 26 and 27, 2020. The conference, held via the Zoom platform, gathered some twenty participants from ten countries (Hungary, Czechia, Slovakia, Poland, Bulgaria, Croatia, Serbia, the USA, Canada, and China), and many observers scholars, researchers and students from Hungary and abroad. All presentations at the conference were in English language. 
The opening speeches were given by Balázs Nagy and His excellency Batbayar Zeneemyadar, ambassador of Mongolia to Hungary. The keynote lecture by Christopher Atwood (University of Pennsylvania) titled "Mongolian Sources on the Great Western Expedition: Some Analytical Comments" closed the first day of the conference. The remaining papers were divided into seven sessions - the three took place on the first, and rest on the second day of the conference.

The papers covered various topics and themes related to the Mongol Invasion of the Central Europe in 1241-1242 and its historical importance, including the problems of the written sources (papers presented by Balázs Nagy, Stephen Pow, Zsuzsanna Papp Reed, Adam Lubocki, Tomaš Somer, and Mirko Sardelić), Cuman migrations on the eve of the Mongol invasion (presentations of Alexander Nikolov and Konstantin Golev), archaeological, climatological and geographic aspects of the Mongol invasion (Zsolt Pinke, József Laszlovszky, Michal Holeščák, Beatrix Romhányi, and Béla Zsolt Szakács), oral tradition (Ágnes Birtalan), nomadic customs (Dorottya Uhrin), relations between the Christian Europe and the Tatar world in the years following the Mongol invasion (Attila Bárány, Ning Ya, and Aleksandar Uzelac), and educational online materials about the Mongol Empire (Jack Wilson). Uzelac also used the opportunity to share information about the newly launched International Association of the Researchers of the Golden Horde.

All lectures, presentations and fruitful discussions that followed them will be posted online at the website of the Project (http://tatarjaras1241.elte.hu) in December 2020 .

At the closing of the conference, the organisers announced that the proceedings are intended to be published during the next year. This volume is expected to be a useful addition to the existing literature in the field of the relations between the Mongol Empire and Medieval Europe, especially considering the importance of the closer mutual collaboration between historians and archaeologists from various countries of Central and Southeast Europe, which was emphasized as one of the primary goals of the event.

About the author: Aleksandar Uzelac - Ph.D. (History), Senior Research Associate, Institute of History, Belgrade (36/II, Kneza Mihaila Str., Belgrade 11000, Serbia); ORCID: 0000-0003-0626-2928. E-mail: aleksandar.uzelac@iib.ac.rs 


\title{
МЕЖДУНАРОДНАЯ ОНЛАЙН-КОНФЕРЕНЦИЯ «МОНГОЛЫ В ЦЕНТРАЛЬНОЙ ЕВРОПЕ: ПРОФИЛЬ И ВЛИЯНИЕ ИХ ВТОРЖЕНИЙ В ХІІІ ВЕКЕ» (БУДАПЕШТ, 26-27 НОЯБРЯ 2020 г.)
}

\author{
Александар Узелац \\ Институт истории, Белград \\ Белград, Сербия \\ aleksandar.uzelac@iib.ac.rs
}

\begin{abstract}
26-27 ноября 2020 г. в Будапеште состоялась международная онлайн-конференция «Монголы в Центральной Европе: профиль и влияние их вторжений в XIII веке». Конференция была организована в рамках проекта «Монгольское вторжение в Венгрию в его евразийском контексте», возглавляемого проф. Балажем Надь. На конференции собралось около двадцати участников из десяти стран. Сборник материалов будет опубликован в 2021 г. и будет полезным дополнением к существующей литературе в сфере отношений между Монгольской империей и средневековой Европой, особенно учитывая важность более тесного сотрудничества между историками и археологами из разных стран Центральной и Юго-Восточной Европы. Это было представлено как одна из основных целей конференции.
\end{abstract}

Ключевые слова: онлайн-конференция, монгольское нашествие в Европу, средневековая Венгрия, Центральная Европа, источниковедение, археология

Для цитирования: Uzelac A. International Online Conference "The Mongols in Central Europe: The Profile and Impact of Their thirteenth-century Invasions" (Budapest, November 26-27, 2020) // Золотоордынское обозрение. 2021. Т. 9, № 1. С. 224-226. DOI: $10.22378 / 2313-6197.2021-9-1.224-226$

Сведения об авторе: Александар Узелац - Ph.D. (история), старший научный сотрудник Института истории, Белград (11000, ул. Кнеза Михаила, 36/II, Белград, Сербия); ORCID: 0000-0003-0626-2928. E-mail: aleksandar.uzelac@iib.ac.rs 